\title{
Pengaruh Cara Aplikasi Pasta Gigi Herbal terhadap Produksi Volatile Sulfur Compound
}

\author{
Suryono \\ Departemen Periodonsia, Fakultas Kedokteran Gigi, Universitas Gadjah Mada, Yogyakarta, Indonesia \\ JI Denta No 1 Sekip Utara, Yogyakarta, Indonesia; e-mail: winsuryo@hotmail.com
}

\begin{abstract}
ABSTRAK
Volatile Sulfur Compound (VSC) merupakan komponen gas yang dihasilkan oleh bakteri dalam rongga mulut, terdiri dari Hidrogen sulfide, Methyl Mercaptan dan Dimethyl Sulfide. Ketiga komponen gas tersebut sering digunakan sebagai indikator untuk menilai status bau mulut seseorang. Pasta gigi berbasis herbal telah dilaporkan pada penelitian sebelumnya mampu menghambat pertumbuhan kuman penyebab penyakit periodontal. Bakteri plak dalam rongga mulut dapat dikurangi melalui cara gosok gigi dan/atau penggunaan material antiseptik. Dua kelompok subjek terpilih diberikan perlakuan dengan menggunakan pasta gigi herbal dengan cara yang berbeda, kelompok pertama dengan cara menggosok gigi dengan pasta gigi herbal sesuai dengan cara yang sudah biasa mereka lakukan dan kelompok ke-2 diberikan perlakuan dengan cara mengoleskan pasta herbal di daerah molar kiri dan kanan rahang atas. Pengambilan sampel nafas dilakukan sebelum perlakuan, 5 menit dan 2 jam paska menggosok gigi atau mengoles pasta herbal. Hasil pengamatan menunjukkan bahwa penggunaan pasta gigi herbal dengan cara sikat gigi maupun pengolesan memiliki pola yang sama pada masing-masing komponen gas sulfur yaitu peningkatan pada lima menit paska aplikasi kemudian menurun pada 2 jam paska aplikasi. Pasta gigi herbal yang diaplikasikan dengan cara gosok gigi maupun dengan cara pengolesan mempengaruhi kadar VSC yaitu yaitu menurunkan kadar Hydrogen sulfide, relatif stabil kadar methyl mercaptan dan terjadi peningkatan kadar dimethyl sulfide. Pasta gigi berbasis herbal dapat digunakan dengan cara sikat gigi maupun pengolesan untuk menurunkan kadar gas VSC, khususnya Hydrogen sulfide pada subjek normal.
\end{abstract}

Maj Ked Gi Ind. Desember 2015; 1(2): 172 - 175

Kata kunci: Pasta berbasis herbal, gosok gigi, pengolesan, volatile sulfur compound

\begin{abstract}
Effect of Herbal Toothpaste Application Method on Production of Volatile Sulfur Compound. Volatile sulfur compound (VSC) is a component of the gas produced by bacteria in the oral cavity, consisting of hydrogen sulfide, methyl mercaptan and dimethyl sulfide. This gas is often used as an indicator to assess the status of bad breath. Herbalbased dental paste has been reported in previous studies to inhibit the growth of germs that cause periodontal disease. Plaque Bacteria in the oral cavity can be reduced by tooth brushing and/or the use of antiseptic material. Two groups of subjects chosen were given treatment using herbal toothpaste in different ways: the first group was by brushing teeth with herbal toothpaste the way they usually do it and the second group was given the treatment by applying herbal paste in the left and right molar region of maxilla. The sampling was performed before treatment, 5 minutes and 2 hours after brushing teeth or applying herbal paste. The result of the experiment indicates that the use of herbal toothpaste with toothbrush and applying method has the same pattern on each component of the sulfur gas that is an increase after five minutes post-application and then a decrease after 2 hours post-application. Herbal toothpaste which is applied by means of brushing or by applying to the teeth affected the levels of VSC components; the level of Hydrogen sulfide decreased, the level of methyl mercaptan was relatively stable, and the level of dimethyl sulfide increased. Herbal toothpaste can be used in a common brushing way or by applying it to the teeth to reduce the levels of VSC gases, especially Hydrogen sulfide in normal subjects.
\end{abstract}

Maj Ked Gi Ind. Desember 2015; 1(2): 172 - 175

Keywords: Herbal-based pasta, brush, application, volatile sulfur compound

\section{PENDAHULUAN}

Penyakit periodontal merupakan penyakit infeksi yang memiliki prevalensi tinggi dan dapat mempengaruhi kondisi sistemik pasien. ${ }^{1}$ Kerusakan yang terjadi pada jaringan periodontal disebabkan oleh faktor mikrobial dan non mikrobial. Faktor mikrobial dikaitkan dengan keberadaan kuman yang ada dalam plak, yang bisa menyebabkan terjadinya kerusakan gigi maupun terjadinya penyakit periodontal. ${ }^{2,3}$ Bakteri yang berada di dalam plak akan menghasilkan suatu produk berupa enzim (kolagenase dan protease), toksin (endotoksin dan eksotoksin), antigen bakteri, dan produk samping bakteri seperti hidrogen sulfide dan amonium yang dapat menyebabkan penyakit dan kerusakan. ${ }^{4}$ Volatile Sulfur Compound (VSC) merupakan gas 
yang mudah menguap yang diproduksi oleh bakteri rongga mulut, yang teridiri dari hydrogen sulfide, methyl mercaptan, dan dimethyl sulfide. Hydrogen sulfide, merupakan produk samping yang dihasilkan oleh kuman periodontopatik yang berdampak pada bau mulut, bersama senyawa sulfide lainnya yaitu methyl mercaptan dan dimethyl sulfide. Komponen senyawa sulfur (VSC) berkorelasi positif terhadap penyakit periodontal yang ditandai dengan kedalaman poket. ${ }^{5}$

Plak dapat dikurangi akumulasinya melalui tindakan mekanis dan kimiawi melalui gosok gigi dan penggunaan antiseptik. Pada peneiltian sebelumnya pasta gigi berbahan aktif herbal mempunyai kemampuan menghambat pertumbuhan kuman bakteri penyebab penyakit periodontal setara dengan positif kontrol chlorhexidine. ${ }^{6}$ Studi korelasi yang dilakukan oleh beberapa peneliti menunjukkan bahwa penurunan jumlah bakteri akan menurunkan kadar gas sulfide..$^{5,7}$ Penelitian ini bertujuan untuk mengetahui efek penggunaan pasta gigi berbasis herbal terhadap perubahan kadar VSC baik yang diaplikasikan dengan cara gosok gigi maupun dengan cara pengolesan pada gigi

\section{METODE PENELITIAN}

Studi dilakukan di RSGM Prof Soedomo FKG UGM, subjek dengan kriteria usia remaja, tidak merokok, tidak mempunyai penyakit sistemik dan tidak mengkonsumsi antibiotik. Subjek diikutkan dalam penelitian setelah mendapatkan penjelasan dan menyetujui untuk menjadi subjek penelitian.

Dua puluh empat subjek normal/non halitosis dibagi menjadi dua kelompok untuk kemudian diberikan instruksi tentang cara pemakaian pasta dan kesiapan yang harus dilakukan untuk setiap subjek; subjek tidak diperkenankan makan 2 jam sebelum dilakukan pengukuran hingga 2 jam paska mengukuran terakhir. Kelompok pertama diberikan instruksi untuk menggosok gigi dengan pasta herbal dengan metode seperti yang dilakukan dalam keseharian, sedang kelompok kedua diberikan instruksi dengan hanya mengoleskan pasta gigi di daerah molar rahang atas. Pengambilan sampel udara dalam mulut dilakukan dengan menggunakan spuit injeksi sebanyak 0,8 ml mulai sebelum melakukan gosok gigi dengan pasta herbal atau mengoleskan pasta herbal, pengukuran berikutnya dilakukan kemudian 5 menit dan 2 jam paska gosok gigi atau pengolesan dengan herbal.

Sampel yang berupa udara dari dalam mulut, diinjeksikan sejumlah 0,5 ml ke dalam alat pengukur gas sulfur (Oral Chroma). Pengamatan kadar gas meliputi hydrogen sulfide, methyl mercaptan dan dimethyl sulfide. Kadar gas ditunjukkan dalam ppb atau ng/10 ml. Protokol penelitian telah dilakukan review oleh Komite Etik Penelitian Kesehatan FKG UGM, dan telah mendapatkan persetujuan kelayakan etik.

\section{PEMBAHASAN}

Hasil pengukuran dalam satuan $\mathrm{ng} / 10 \mathrm{ml}$ atau ppb kadar VSC yang meliputi hydrogen sulfide, methyl mercaptan dan dimethyl sulfide.

Tabel 1. Mean dan standar deviasi kadar hydrogen sulfide, methyl mercaptan, dan dimethyl sulfide pada penggunaan pasta gigi herbal dengan perlakuan gosok gigi dan pengolesan

\begin{tabular}{|c|c|c|c|c|}
\hline & GOSOK GIGI & & OLES & (ng/10ml) \\
\hline $\mathrm{H} 2 \mathrm{~S}$ & Mean (S) & $\mathrm{SD}(\mathrm{S})$ & Mean (O) & $\mathrm{SD}(\mathrm{O})$ \\
\hline before & 0.05 & 0.08 & 0.00 & 0.00 \\
\hline Ater 5 minute & 0.16 & 0.25 & 0.05 & 0.16 \\
\hline \multirow[t]{2}{*}{ after 2 hours } & 0.00 & 0.04 & 0.00 & 0.00 \\
\hline & GosoK GIGI & & OLES & (ng/10ml) \\
\hline $\mathrm{CH} 3 \mathrm{SH}$ & Mean (S) & $\mathrm{SD}(\mathrm{S})$ & Mean $(\mathrm{O})$ & $\mathrm{SD}(\mathrm{O})$ \\
\hline before & 0.11 & 0.79 & 0.22 & 0.42 \\
\hline Ater 5 minute & 0.26 & 2.96 & 3.71 . & 5.21 \\
\hline \multirow[t]{2}{*}{ after 2 hours } & 0.70 & 0.60 & 0.27 & 0.82 \\
\hline & GosoK GIGI & & OLES & (ng/10ml) \\
\hline (CH3)2S & Mean (S) & $\mathrm{SD}(\mathrm{S})$ & Mean $(\mathrm{O})$ & $\mathrm{SD}(\mathrm{O})$ \\
\hline before & 0.56 & 0.63 & 2.08 & 1.35 \\
\hline Ater 5 minute & 0.75 & 0.80 & 1.11 & 2.13 \\
\hline \multirow[t]{2}{*}{ after 2 hours } & 4.08 & 4.60 & 2.46 & 2.55 \\
\hline & GosoK GIGI & & OLES & (ng/10ml) \\
\hline $\mathrm{H} 2 \mathrm{~S}$ & Mean (S) & $\mathrm{SD}(\mathrm{S})$ & Mean (O) & $\mathrm{SD}(\mathrm{O})$ \\
\hline before & 0.05 & 0.08 & 0.00 & 0.00 \\
\hline Ater 5 minute & 0.16 & 0.25 & 0.05 & 0.16 \\
\hline \multirow[t]{2}{*}{ after 2 hours } & 0.00 & 0.04 & 0.00 & 0.00 \\
\hline & GOSOK GIGI & & OLES & (ng/10ml) \\
\hline $\mathrm{CH} 3 \mathrm{SH}$ & Mean (S) & $\mathrm{SD}(\mathrm{S})$ & Mean (O) & $\mathrm{SD}(\mathrm{O})$ \\
\hline before & 0.11 & 0.79 & 0.22 & 0.42 \\
\hline Ater 5 minute & 0.26 & 2.96 & 3.71 . & 5.21 \\
\hline \multirow[t]{2}{*}{ after 2 hours } & 0.70 & 0.60 & 0.27 & 0.82 \\
\hline & GosoK GIGI & & OLES & (ng/10ml) \\
\hline$(\mathrm{CH} 3) 2 \mathrm{~S}$ & Mean (S) & $\mathrm{SD}(\mathrm{S})$ & Mean (O) & $\mathrm{SD}(\mathrm{O})$ \\
\hline before & 0.56 & 0.63 & 2.08 & 1.35 \\
\hline Ater 5 minute & 0.75 & 0.80 & 1.11 & 2.13 \\
\hline after 2 hours & 4.08 & 4.60 & 2.46 & 2.55 \\
\hline
\end{tabular}


Hasil pengukuran pengaruh cara aplikasi pasta gigi herbal terhadap produksi VSC menunjukkan pola yang sama bahwa produksi gas hydrogen sulfide, methyl mercaptan, dan dimethyl sulfide memiliki kemiripan pada pengukuran sebelum, 5 menit dan 2 jam paska perlakuan, yaitu naik pada 5 menit paska aplikasi dan menurun paska 2 jam. Penurunan komponen VSC hanya terjadi pada hydrogen sulfide, senyawa gas ini produksinya banyak dikaitkan dengan kelompok individu dengan jaringan periodontal yang sehat.

Bau nafas bersumber dari sistem pernafasan dan pencernaan yang sebagian besar berasal lokal dari dalam mulut. Akumulasi makanan, bakteri dan sel epithelial dari lidah yang terdegradasi oleh bakteri akan menghasilkan bau mulut. ${ }^{9}$ Metabolisme bakteri gram negative anaerob seperti Porphyromonas, Prevotella, Treponema, Actinobacillus dan Fusobacterium yang hidup dalam rongga mulut akan memproduksi VSC. ${ }^{10}$ Penelitian Sroisiri and Boonyanit (2011) menunjukkan bahwa hasil evaluasi pada subjek normal yang diberikan perlakukan dengan sikat gigi dan berkumur dengan antiseptik dapat menurunkan kandungan gas VSC pada pengamatan jangka pendek, dan bisa memberikan efek hingga 12 jam produksi gas VSC oleh bakteri lidah. ${ }^{11}$ Penurunan kadar VSC ini sejalan dengan hasil penelitian Ikawa et al, yang menyatakan bahwa VSC sangat berhubungan dekat dengan asupan makanan dan gosok gigi. ${ }^{12}$ Penggunaan herbal sangat dikaitkan dengan kemampuan antibakterialnya, sehingga bisa menurunkan produksi VSC yang dihasilkan oleh kuman penyebab penyakit periodontal. Kumar et al, melaporkan dalam reviewnya bahwa sebagian besar herbal yang telah mendapatkan patent mempunyai potensi yang besar untuk pengobatan penyakit periodontal, karena kemampuan antibakterinya. ${ }^{13}$

Gas hydrogen sulfide dihasilkan oleh sebagian besar kuman yang hidup ada pada daerah lidah, khususnya pada daerah pangkal lidah, hasil dari metabolisme bakteri terhadap sel epitel lidah yang terkelupas akan meningkatkan komponen gas ini. Studi yang dilakukan pada subjek non halitosis menunjukkan bahwa kadar hidrogen sulfide dapat diturunkan atau dipertahankan pada level 0 setelah
2 jam paska aplikasi pasta herbal baik dengan cara penyikatan maupun pengolesan. Penurunan ini dimungkinkan karena efek antibakterial yang ada dalam pasta herbal mampu mengurangi populasi bakteri yang ada pada lidah, sehingga proses metabolisme terhadap substrat organik yang ada dalam saliva atau menempel pada lidah dapat dihambat melalui mekanisme penghancuran dinding sel maupun penghambatan proses enzimatik bakteri.

Tidak terdapat perbedaan antara cara aplikasi pasta baik dengan cara gosok gigi maupun pengolesan terhadap produksi hydrogen sulfide, methyl mercaptan dan dimethyl sulfide. Methyl mercaptan dan dimethyl sulfide merupakan gas yang dikaitkan produksinya pada kondisi terjadi penyakit periodontal. Status kesehatan jaringan periodontal, oleh karena itu peningkatan kedua jenis gas ini bisa diakibatkan adanya penyakit periodontal, dan gas dihasilkan oleh kuman anaerob yang ada dalam poket periodontal. Gosok gigi maupun aplikasi topikal yang sifatnya superfisial tidak bisa memberikan efek pada kuman yang hidup di dalam sulkus. Perlu pembuktian lebih lanjut melalui evaluasi jangka panjang dan pada subjek periodontitis agar bisa diketahui efek cara aplikasi dari pasta berbasis herbal terhadap produksi gas VSC.

Pada kondisi subjek normal dengan tidak terdiagnosis sebagai penderita halitosis atau tanpa klasifikasi penyakit periodontalnya dapat disimpulkan bahwa melakukan sikat gigi atau pengolesan dengan pasta gigi berbahan aktif herbal efektif untuk menurunkan kadar hydrogen sulfide yang merupakan komponen utama volatile sulphur compound penyebab bau mulut.

\section{DAFTAR PUSTAKA}

1. Tobias K, Boehm, Frank A. Scannapieco. The epidemiology, consequences and management of periodontal disease in older adults. JADA. 2007; 138: 26S-33S.

2. Haake SK, Nisengard RJ, Newman MG, Miyasaki KT. Microbial Interactions with the Host in Periodontal Diseases in: Newman MG, 
Takei HH, Carranza FA. Carranza's Clinical Periodontology $9^{\text {th }}$ ed. Sydney. Toronto. WB Saunders Company. 2002.

3. Bueltmann K, Stillman N. Periodontal Disease and the Female Patient. Glenview: American Academy of Periodontology; 2002.

4. Newman, Takei. Carranza Clinical Periodontology. Elsevier. 2012.

5. Quirynen. Management of oral malodour. J Clin Periodontol. 2003; 30: 17-18.

6. Suryono. Daya antibakteri berbagai pasta gigi yang beredar dipasaran terhadap bakteri penyebab penyakit periodontal. Laporan Penelitian Dana Masyarakat FKG UGM. 2013.

7. Verkaik MJ, Busscher HJ, Jager D, Slomp AM, Abbas F. Mei efficacy of natural antimicrobials in toothpaste formulations against oral biofilms in vitro. J Dent. 2010; 1-7.

8. Van den Broek AM, Feenstra L, de Baat C. A review of the current literature on management of halitosis. Oral Dis 2008. 14: 30-9.
9. Porter SR, Scully C. Oral malodour (halitosis). Br Med J. 2006. 333: 632-5.

10. Van den Broek AM, Feenstra L, de Baat C. A review of the current literature on management of halitosis. Oral Dis. 2008; 14: 30-9.

11. Sroisiri $T$, Boonyanit $T$. Effect of an essential oil-containing mouth rinse on VSC-producing bacteria on the tongue. Southeast Asian J Trop Med Public Health. 2011; 42(2): 456-462.

12. Ikawa K, Iwakura M, Washio J, Kusano A, Tanda N, Koseki T. Circadian changes of volatile sulfur compounds measured by Breathtron. International Congress Series 1284. 2005; 89-90.

13. Kumar P, Ansari SH, Ali J. Herbal Remedies for treatment of Periodontal disease-A Patent Review. Recent Patent on Drug Delivery and Formulation. 2009; 221-228. 